\title{
ARTICLE
}

\section{BEYOND MATURITY: MASS TORT CASE MANAGEMENT IN THE MANUAL FOR COMPLEX LITIGATION}

\section{THOMAS E. WILLGING ${ }^{\dagger}$}

This Article discusses aspects of the past, present, and future treatment of mass torts in the Manual for Complex Litigation ("Manual" or " $M C L$ "). The Article develops the following story.

Some lawyers and judges have used the Manual like a treatise. A danger of such use is that the Manual may discuss a novel concept simply to encourage innovation and testing. Enshrining an innovative idea into a rule of law can lead to the premature creation of rigid legal rules. In the end, such rigidity can inhibit the innovative case management that the Manual is designed to promote. Mass tort litigation is exceedingly complex, involving widely differing congregations of multifaceted cases. A manual, with its inherent tendency to present rules of thumb, can fall prey to the temptation to oversimplify the factors that judges should consider when deciding, for example, whether to aggregate a group of tort cases. By presenting alternative, multidimensional approaches, some of which are sketched out in the last Part of this Article, a manual might avoid prematurely creating rigid rules.

Part I describes the Manual and its evolution. Part II uses the Manuals treatment of the concept of maturity in mass tort litigation and one court's reliance on that treatment as a case study to assess the role the Manual should play in the development of practices, procedures, and legal rules that might be applied to mass torts. Part III presents a critical evaluation of the maturity concept, examining how maturity would have applied to past and present mass tort congregations,

$\dagger$ Senior researcher at the Federal Judicial Center; in that capacity, I served as principal drafter of the mass tort section of the third edition of the Manual for Complex Litigation and currently serve as staff to the newly appointed Board of Editors for the Manual. The views presented are my own and do not necessarily reflect the views of the Federal Judicial Center or the Board of Editors. I gratefully acknowledge the thorough research assistance of Kristina Gill of George Washington University Law School and the insightful comments of William W Schwarzer, Russell Wheeler, and Jennifer Evans Marsh on an earlier draft of this Article. 
challenging the premises underlying the general concept, and analyzing one alternative approach in which maturity would not be isolated from other factors affecting mass tort case management. Part IV addresses some of those other factors and considers one alternative for treating maturity differently in future versions of the Manual.

\section{WHAT IS THE MANUAL FOR COMPLEX LITIGATIONAND HOW HAS IT EVOLVED?}

\section{A. A Precursor to the Manual}

The Judicial Conference adopted the precursor to the Manual, entitled Handbook of Recommended Procedures for the Trial of Protracted Cases ("Handbook"), in March 1960. A special panel of judges, appointed by Chief Justice Earl Warren in 1955 to serve as the Judicial Conference's Study Group on Protracted Litigation, developed the procedures in the Handbook. Working in consultation with leading trial lawyers, the study group served under the auspices of the Pretrial Committee of the Judicial Conference chaired by Alfred P. Murrah, then-Chief Judge of the Court of Appeals for the Tenth Circuit. Their mission was to uncover and make accessible to bench and bar the "great reservoir of experience in the conduct of protracted litigation accumulated over the years and lying dormant within the legal profession." ${ }^{2}$

The Handbook produced by the study group was "designed as a tool, available for use by... [whomever] chooses to use it. ${ }^{3}$ The judges in the study group saw the prototypical problem as the "Big Case," which they identified as an antitrust case, a patent case, or a case involving high stakes or a large number of parties. ${ }^{4}$ At the time the Handbook was written, the judiciary had not yet experienced the flood of small or medium-sized cases that, when added together, form the fodder for what we now call mass torts.

The core research method for producing the Handbook was to collect the experiences of judges and lawyers about case management techniques. The purpose of the Handbook was to pass these experiences along to others who might confront similar "Big Cases." The

\footnotetext{
I 25 F.R.D. 351 (1960) [hereinafter HANDBOOK].

2 Id. at 355 (Foreword by Judge Alfred P. Murrah).

${ }^{3}$ Id. at 359 (Preface by Judge E. Barrett Prettyman).

"Id. at 375. The term "Big Case" is capitalized in the original Handbook.

${ }^{5}$ A series of three seminars was held at law schools in the late 1950s. See
} 
method was experiential in the broad sense that it drew on real, albeit anecdotal, litigation activity, as opposed to simply published opinions or other authorities. A reader of the Handbook is more likely to find footnotes citing discussions at seminars, reports from conferences, or unpublished case anecdotes, than to find footnotes citing published opinions. ${ }^{6}$

For the most part, as its title asserts, the Handbook packaged suggestions in the form of recommendations to judges and lawyers. While the recommendations were presented in bold black lettersperhaps hinting at or inviting readers to see them as authoritativethe tone was managerial and for the most part deferential to existing rules. For example, on the use of special masters, the judges recommended that "[a] protracted case should not, in the absence of agreement by the parties, be referred in its entirety to a master," but "a master may perform useful functions, in aid of the assigned judge, on limited and specified matters such as fact reporting on preliminary matters, or complicated and involved accountings." "Later, the judges recommended considering use of a master to supervise discovery in exceptional cases, and carefully followed case law principles that "special masters should not be appointed automatically," nor "utilized as substitutes for the trial judge. ${ }^{8}$

Notably, the Handbook's recommendations were posited as "rules" to govern the "Big Case." The black-letter format and the absence of

HANDBOOK, supra note 1, at 373 n.I (citing unpublished proceedings of Seminar held at University of Colorado School of Law, July 13-15, 1959); Proceedings of the Seminars on Protracted Cases for the United States Judges Held at the School of Law Stanford University, Stanford, Cal., Aug. 18-22, 1958, 23 F.R.D. 319 (1958); Proceedings of the Seminar on Protracted Cases for United States Circuit and District Judges Held at New York University Law Center, New York City, Aug. 26-30, 1957, 21 F.R.D. 395 (1957). Earlier, in 1951, the Judicial Conference adopted a report issued by a committee of judges chaired by Chief Judge E. Barrett Prettyman of the United States Court of Appeals for the D.C. Circuit that came to be known as the Prettyman Report. SeeHon. Leon R. Yankwich, "Short Cuts" in Long Cases: A Commentary on the Report Entitled Procedure in Anti-Trust and Other Protracted Cases Adopted by the Judicial Conference of the United States, Sept. 26, 1951, 13 F.R.D. 41, 6284 (1953) (providing the full text of the Report, Procedure in Anti-Trust and Other Protracted Cases).

${ }^{6}$ Of the 139 footnotes in the Handbook, 102 references were to reports or seminars. Sixty-two of these references were to the three seminars described supra note 5, 26 were to the Prettyman Report, supra note 5, and 14 were to two American Bar Association committee reports that were first cited in the Handbook at page 373 , note 1 . In contrast to the 102 references to reports or seminars, there were 72 references to cases, many of which had been discussed at the seminars and were unpublished. Many footnotes, of course, contained more than one reference.

${ }^{7}$ HANDBOOK, supra note 1, at 381-82.

${ }^{8} I d$. at 390. These principles are articulated in La Buy v. Howes Leather Co., 352 U.S. 249, 256-59 (1957). 
alternative recommendations imply as much. Clearly the alternative of doing nothing was not acceptable, and the Handbook did not encourage judges to fashion their own approaches.

More often, recommendations in the Handbook did not directly come into contact with applicable law but rather dealt with discretionary managerial functions. For example, the Handbook recommended: "When a protracted case is identified, the assigned judge should, at the earliest moment, take ... control of the case. ${ }^{99}$ More specific recommendations for taking control of a case-for example, by holding early pretrial conferences and controlling discovery-were not explicitly authorized or prohibited by existing rules.

\section{B. MCL (First Edition)}

In 1969, the first edition of the Manual, prepared by a Board of Editors specially appointed by the Federal Judicial Center, was published under the title Manual for Complex and Multi-District Litigation ("MCL"). Congress had created the Center in December 1967 to "conduct research and study ... the operation" ${ }^{\text {"10 }}$ of the federal courts and "to stimulate, create, develop, and conduct programs of continuing education and training for personnel of the judicial branch" of the federal government. ${ }^{11}$ For purposes of this Article, it is important to note that the Center has no authority to take actions that are binding on the judiciary or on individual judges. Courts and judges, in other words, are under no legal or administrative obligation to follow any suggestions they may receive from Center education or research.

When Justice Tom C. Clark, the first director of the Center, appointed the first Board of Editors, he seized an opportunity for the Center to address some pressing needs of the courts. As stated in the foreword to the $M C L$, the Center's "research and planning will require time before it affects the operations of the courts.... This Manual is designed to meet some of the current needs of the courts. ${ }^{12}$ As to the intended use and authority of the $M C L$, the six judges who constituted the Board of Editors adopted Judge Murrah's approach as stated in the Handbook, that is, that the $M C L$ " contains neither a simplified outline for the easy disposition of complex litigation nor an in-

9 HANDBOOK, supra note 1 , at 383.

${ }^{10} 28$ U.S.C. $\$ 620$ (b) (I) (1994).

"Id. $\$ 620(\mathrm{~b})(3)$.

12 MANUAL FOR COMPLEX AND MULTi-DisTrict LITIGation iii (West 1969) [hereinafter MCL]. 
flexible formula or mold into which all trial and pre-trial procedures must be cast." 13 The procedures are recommended because they are "the product of experience and the development of able minds.", In the end, "flexibility should be the keynote in applying the suggestions contained in this Manual. ${ }^{\text {,15 }}$

The text of the $M C L$, however, struck a more imperative tone than the Handbook, and could be read as directing specific procedures and agendas for each stage of the litigation. For example, the editors asserted that "experience has demonstrated that in a complex case orderly discovery requires that the first wave of discovery be accompanied by plans for full discovery in two successive waves. ${ }^{\text {16 }}$ In a similar tone, the editors stated that a "crucial step in the first phase of judicial management of complex cases is the prompt entry of an order staying all pretrial proceedings until an initial schedule of discovery is approved."17 The text set forth fixed agendas for the First Principal (Preliminary) Pretrial Conference ${ }^{18}$ and for the Second Principal Pretrial Conference. Without commenting on the wisdom of these apparent mandates-and without reliable empirical evidence about how frequently they were followed-one can only say that the Manual presents its guidance as a set of authoritatively stated procedural guidelines. Other than the disclaimer in the Foreword, no limitations suggest that these guidelines should not govern all of the subset of litigation classified as complex.

The text of the $M C L$ indicates that the authors moved beyond presenting suggestions for management and sought to influence the development of the law. For example, the $M C L$ 's treatment of survey samples and opinion polls suggests that the editors were aware that their text might be used as persuasive authority in interpreting and expanding the law relating to admissibility of surveys. As one commentator has noted, before the adoption of the Federal Rules of Evi-

${ }^{13}$ Id. at xix (quoting HANDBOOK, supra note 1, at 355). The Manual for Complex Litigation, Second opens by quoting that same statement. See MANUAL FOR COMPLEX LITIGATION \$ 10, at 1 (2d ed. 1985) [hereinafter MCL 2D].

${ }^{14} \mathrm{MCL}$, supra note 12 , at xii (quoting HANDBOOK, supra note 1, at 355).

${ }^{15} I d$ at xiii.

${ }^{16}$ Id. $\S 1.7$, at 15 (emphasis added).

${ }^{17} I d$. $\$ 1.1$, at 11 (emphasis added). As seen in the emphasized words, the $M C L$ made the specific content and timing of the order unmistakably clear.

${ }^{18}$ See id. § 1.0, at 10 .

${ }^{19}$ See id. $\$ 2.0$, at 17-18. For example, the $M C L$ instructs that at this conference the judge should "(a) determine the class action issue, (b) determine preliminary legal questions, (c) rule on requests for discovery scheduled by the first pretrial conference (first wave of discovery)," and perform other such functions. Id. at 17. 
dence in 1975, "the question whether surveys constituted acceptable evidence... was unsettled. ${ }^{20}$ Doubts about admissibility of surveys "centered on their use of sampling techniques and their status as hearsay evidence. ${ }^{21}$ In 1969, the MCL's black-letter recommendation on use of samples and polls stated that "[s]cientifically designed samples and polls, meeting the tests of necessity and trustworthiness, are useful adjuncts to conventional methods of proof and may contribute materially to shortening the trial of the complex case. ${ }^{22}$ The implication seems clear enough: valid surveys probative of a material fact should be admitted into evidence. Almost five pages of background discussion supporting this recommendation put forth arguments for the admissibility of samples and polls, citing only cases in which such materials were found to be admissible. ${ }^{23}$ The discussion noted that "[t] he principal objection to the admission of both samples and polls has been that such evidence is hearsay" and concluded that "[c] ourts now admit samples and polls over the hearsay objection on the grounds that surveys are not hearsay. ${ }^{24}$

${ }^{20}$ DAVID L. FAIGMAN ET AL., 1 MODERN SCIENIIFIC EVIDENCE 187 (1997). A recent case shows that the admissibility of surveys as evidence is not entirely settled. See Schering Corp. v. Pfizer Inc., 189 F.3d 218, 224-40 (2d Cir. 1999) (reversing and remanding a decision by the district court to exclude five surveys based on a hearsay objection, holding that two surveys were admissible under the state of mind exception in Federal Rule of Evidence 803 (3) and that the other surveys were to be reconsidered as to their trustworthiness and necessity under the residual hearsay rule, Federal Rule of Evidence 807).

${ }_{21}$ FAIGMAN ET AL., supra note 20, at 187. For examples of the exclusion of surveys based on hearsay objections, see Colorificio Italiano Max Mejer, S.P.A. v. S/S Hellenic Wave, 419 F.2d 223, 225-26 (5th Cir. 1969), and Northerm California Pharmaceutical Ass'n v. United States, 306 F.2d 379, 391 (9th Cir. 1962). For an oft-cited case rejecting hearsay objections to a properly conducted survey, see Zippo Manufacturing Co. v. Rogers Imports, Inc., 216 F. Supp. 670, 680-84 (S.D.N.Y. 1963).

${ }_{22}$ MCL, supra note $12, \S 2.612$, at 22.

${ }^{23}$ See id. at 23-27 (supporting the recommendation in favor of the usefulness and admissibility of samples and polls).

${ }_{24}$ Id. at 23-24. The drafters cited cases from the early $1950 \mathrm{~s}$, including one federal court of appeals case decided in 1951, two district court cases, and one state case. The court also cited the classic 1963 Zippo case, "a scholarly opinion by Feinberg, J." Id. at 24 n.39. The $M C L 2 d$ and the $M C L 3 d$ continued to assert that properly-conducted surveys are admissible, but by the time of their publication, the law had become more settled because of the promulgation of the Federal Rules of Evidence. See MCL 2D, supra note $13, \S 21.484$, at $88-89$ (opining on the usefulness of statistical evidence such as surveys); MANUAL FOR COMPLEX LITIGATION, THIRD $\$ 21.493$, at 101-03 (1995) [hereinafter MCL 3D] (same). As observed supra note 20, however, the law is not entirely settled. 


\section{MCL $2 \mathrm{~d}$}

Whatever the intent of the drafters, the $M C L$ came to be perceived as mandating the rote application of a fixed set of rules. Professor Francis McGovern, who was instrumental in drafting the Manual for Complex Litigation, Second ("MCL $2 d^{\text {") }}$, described the $M C L$ as "prescribing strict guidelines for managing complex cases" and containing "predetermined rules with universal applicability." In contrast, the $M C L 2 d$ was designed to present "a compendium of procedural devices, described in detail, with comments concerning their strengths and weaknesses. ${ }^{26}$ The result is that each "judge or attorney must decide, on a case-by-case basis, when intervention may be desirable and which techniques to use on which cases. ${ }^{27}$

A Board of Editors, appointed by Center director A. Leo Levin and chaired by Judge Sam C. Pointer, Jr., wrote the $M C L 2 d$. It was published in 1985. The eight editors consisted of six federal district judges and two federal appellate judges. Professors Arthur R. Miller and Francis E. McGovern served as "technical advisors. ${ }^{.28}$ The intent of the editors was to shift away from proscribing and prescribing single methods. Instead, they planned to describe a smorgasbord of choices for judges and attorneys. In the introduction, Judge Pointer wrote that " $[t]$ he various techniques suggested... either have been used regularly with success or deserve, in the opinion of the Board of Editors, further use and experimentation in appropriate cases. ${ }^{29}$ In some instances, "the Manual describes alternative procedures that may be used in particular cases to cope with the same problem., ${ }^{30}$ By presenting options, the editors unmistakably disclaimed any intent to establish legal precedents or to be cited as authority in the evolution of procedural law. Nothing deflates a claim to legal authority like an argument in the alternative.

\section{MCL 3d}

The Manual for Complex Litigation Third ("MCL $3 d$ "), released in 1995, was written by "staff of the Federal Judicial Center," led by the

${ }^{25}$ Francis E. McGovern, Toward a Functional Approach for Managing Complex Litigation, 53 U. CHI. L. REV. 440, 448-49 (1986).

\footnotetext{
${ }^{26} \mathrm{Id}$. at 448.

${ }^{27}$ Id. at 449.

${ }^{23}$ MCL 2D, supra note 13 , at iii.

${ }^{29}$ Id. $\$ 10$, at 1 .

${ }^{30}$ Id.
} 
Center's then-Director, Judge William W Schwarzer. ${ }^{31}$ I contributed chapters on mass torts and CERCLA (Superfund) litigation. ${ }^{32}$ The $M C L 3 d$ continues the tradition of $M C L 2 d$ in presenting alternatives. It is, in Judge Schwarzer's introductory words, "a kit of management tools that have proved effective in the past, from which the participants should select those useful for the particular circumstances." ${ }^{33}$ Judge Schwarzer takes pains to note that the $M C L 3 d$ offers "an array of litigation management techniques" and "does not recommend that every litigation necessarily use any of them or follow a standard pattern." ${ }^{, 94}$ Indeed, in its opening pages, in a section called "Use of the Manual," the authors expressly disclaim any citation or use of the $M C L$ $3 d$ as legal authority: "The manual is offered as an aid to management, not as a treatise on matters of substantive or procedural law.... Nor is the manual intended for citation as authority on points of law or as a statement of official policy. ${ }^{35}$

In summary, the Manual appears to have evolved from a set of recommendations into a series of hard-and-fast rules before settling into its current format-a menu of alternative approaches to a changing array of complex litigation. The two most recent editions have catalogued the latest innovations in case management techniques and disavowed any aspirations to alter common law or procedural rules. Given the nonadversarial context in which these editions have been written-especially the recent reliance on staff-the disclaimer of intent to serve as authority seems to give appropriate deference to adversarial development of common law in concrete cases.

\section{THE MANUALAS SOcIAL AUTHORITY}

"Social authority" is a term that Professors John Monahan and Laurens Walker coined to describe the use of an empirical proposition as the equivalent of a legal rule. ${ }^{36}$ Monahan and Walker propose that, before adopting empirical findings, courts should examine them to assure the validity and stability of the scientific underpinnings for

31 MCL 3D, supra note 24, at xiv.

${ }^{32}$ See id.

ss Id. $\$ 10.1$, at 4 .

${ }^{34} I d$.

${ }^{35} I d . \S 10.2$, at 5 .

${ }^{36}$ John Monahan \& Laurens Walker, Social Authority: Obtaining, Evaluating, and Establishing Social Science in Law, 134 U. PA. L. REV. 477, 488 (1986) (arguing that "courts should treat social science research relevant to creating a rule of law as a source of authority rather than as a source of facts"). 
such findings. ${ }^{37}$ This Part uses a case study to illustrate how one court's use of the MCL $3 d$ might be construed as regarding the Manual as social authority without satisfying the criteria that Monahan and Walker posit. The result of using the Manual to formulate legal rules may be that inflexible rules will inhibit judicial case management in fast-changing areas such as mass tort litigation.

The $M C L 2 d$ was the first in the series of manuals to include a chapter on the application of complex litigation principles to the emerging field of what we now call "mass torts." A chapter on "Mass Disasters and Other Complex Tort Cases" consisted of thirteen pages covering seven topics: "Centralized Management," "Organization of Counsel," "Parties and Issues," "Class Actions," "Discovery," "Trial," and "Settlements." Reflecting the times, class actions were covered in a single paragraph that began "[h]eeding the caveat of the Advisory Committee, courts historically have been reluctant to authorize class action treatment of personal injury claims arising from a mass disaster or from discrete uses of, or exposure to, a product at different locations and times." ${ }^{40}$ The chapter goes on to say that "use of Rule 23 is not necessarily impermissible in all mass tort litigation" and that "[c]ourts have only recently begun to consider the propriety of forming a class under Rule 23(b) (1) and (b) (2) in the mass tort context. ${ }^{\text {p11 }}$ Note that the discussion summarizes the experiences of the courts in applying class action rules to mass torts, and presents both the emerging experimentation with class actions and the traditional limits.

Ten years later, in 1995, reflecting the burst of mass tort activity including class action litigation that had taken place in the prior decade, the $M C L 3 d$ expanded the coverage of mass torts considerably. ${ }^{42}$ The subsection on class actions shifts from heeding the caveat against class actions and begins: "Despite the Advisory Committee's 1966 caveat, courts have increasingly utilized class actions to avoid duplicative litigation in mass tort cases, although primarily in the context of settlement." ${ }^{43}$ Again, the presentation discusses the recent experience of courts and indicates that settlement may be a differentiating and limit-

${ }^{37}$ See infra notes $82-90$ and accompanying text.

ss See MCL 2D, supra note 13, § 33.2, at 291-303 (discussing "Mass Disasters and Other Complex Tort Cases").

${ }^{39}$ See id.

${ }^{40} I d . \$ 33.24$, at 298 (emphasis added) (citation omitted).

${ }^{41} I d$.

22 See MCL 3D, supra note 24, $\S 33.2$, at 308-34 (discussing management of and procedures for handling mass tort cases).

is Id. at 324 (emphasis added) (citations omitted). 
ing factor. ${ }^{44}$

In addition to class certification, consolidation represents a second procedure for aggregating claims. The $M C L 3 d$ discusses these two procedures together, after cautioning that "aggregation, whether through consolidation or class action treatment, may not be appropriate for some litigation. ${ }^{25}$ The $M C L 3 d$ goes on to introduce the concept of maturity in positive but probabilistic terms: "In general, those mass torts in which general causation has become relatively clear over time are likely to be candidates for large consolidations or even class action treatment. ${ }^{46}$ In a footnote, the $M C L 3 d$ indicates that "[e]mpirical research suggests that decisions to consolidate or bifurcate trials may affect jury decisions about liability and damages," citing experimental research findings by social psychologists Kenneth Bordens and Irwin Horowitz. ${ }^{47}$

Despite the Manuals coverage, judges and lawyers have not typically managed mass tort litigation by consulting manuals. While judges and lawyers facing a massive and novel set of cases may have used the $M C L 3 d$ as an introductory source of ideas, they have controlled mass tort litigation by fashioning case management tools adapted to the characteristics and needs of each unique group of cases. ${ }^{48}$ The case study that follows does not appear to represent a

14 Soon after publication of the $M C L 3 d$, however, a rapid succession of federal appellate and United States Supreme Court decisions restricted the role of class actions in resolving mass torts in litigation contexts, including settlement. See Amchem Prods., Inc. v. Windsor, 521 U.S. 591 (1997) (decertifying a national Rule 23(b) (3) settlement class of present and future asbestos claimants); Valentino v. Carter-Wallace, Inc., 97 F.3d 1227 (9th Cir. 1996) (vacating national certification under Rule 23(b)(3) and (c) (4) as to liability issues of a class of users of a drug to treat epilepsy); Castano v. American Tobacco Co., 84 F.3d 734 (5th Cir. 1996) (decertifying a national Rule 23(b)(3) litigation class of nicotine-dependent cigarette smokers); In re American Medical Sys., Inc., 75 F.3d 1069 (6th Cir. 1996) (decertifying a national Rule 23(b) (3) litigation class involving penile prostheses users); In re Rhone-Poulenc Rorer, Inc., 51 F.3d 1293 (7th Cir. 1995) (granting mandamus and directing the district court to decertify a national Rule 23(b) (3) and 23(c)(4) litigation class of HrV-infected hemophiliacs as to issues of negligence and breach of fiduciary duty). This trend continues. See Ortiz v. Fibreboard Corp., 527 U.S. 815, 119 S. Ct. 2295 (1999) (decertifying a Rule 23(b) (1) limited fund settlement class of present and future asbestos claimants).

${ }^{45}$ MCL 3D, supra note 24, §33.26, at 322.

${ }^{46} \mathrm{Id}$

${ }^{47}$ Id. $\$ 33.26$, at 322 n.1056 (citing Kenneth S. Bordens \& Irwin A. Horowitz, Mass Tort Civil Litigation: The Impact of Procedural Changes on Jury Decisions, 73 JUDICATURE 22 (1989)).

${ }^{43}$ See generally Peter H. Schuck, Mass Torts: An Institutional Evolutionist Perspective, 80 CORNELL L. REV. 941, 948-50 (1995) (emphasizing the evolution of the mass torts system resulting from selection by judges and other policymakers among competing insti- 
widespread or even typical use of the $M C L 3 d$. The study is a vivid example of the limits of a manual, illustrating that material designed to encourage innovation can become prematurely rigidified into a rule of law.

In one post-1995 case restricting the role of class actions in resolving mass tort litigation, the $M C L 3 d$ played a notable role. In Castano v. American Tobacco Co., the Court of Appeals for the Fifth Circuit decertified a class of up to 50 million tobacco smokers on a number of grounds. ${ }^{49}$ This Article discusses the court's use of the maturity concept, but does not discuss the Castano court's independent analysis of Rule 23 factors, such as the predominance of common issues or aspects of superiority unrelated to the maturity of the underlying claims. The court's conclusion that the putative class should not have been certified as a litigation class is cogent. The court's treatment of maturity and the consequences of focusing on that single factor is less convincing.

As an independent ground for decertifying the class, the Castano court addressed the issue of whether "a class action is superior to other available methods for the fair and efficient adjudication of the controversy. ${ }^{, 50}$ That inquiry, by its terms, invites a comparative analysis of case management options. Examining the Manual as a source of information about alternatives, as the Castano court did, follows naturally from the language of Rule 23 . While the court in analyzing the superiority of the class action approach discussed factors other than maturity, its summary and conclusion suggest that the court saw itself as holding, or at least creating a presumption, that immature mass torts may not be certified as a class under Rule 23(b)(3).

tutional designs); Thomas Willging et al., Individual Characteristics of Mass Torts Case Congregations [hereinafter Willging et al., Individual Characteristics], in ADVISORY COMM. ON CTIL RULES \& WORKING GROUP ON MASS TORTS, REPORT ON MASS TORT LITIGATION app. D (1999) [hereinafter REPORT ON MASS TORT LIMGATION] (examining the characteristics of 50 mass tort cases over a period of almost 50 years in an attempt to identify possible patterns).

${ }^{19} 84$ F.3d at 746-48 (finding not only that the class failed to meet the Rule 23(a) prerequisites, but also that the class failed to meet the Rule 23(b)(3) superiority requirement).

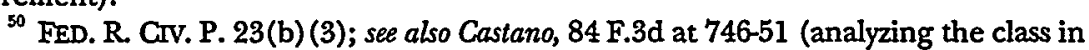
terms of Rule 23(b) (3)'s superiority requirement). One might read the court's ruling as subsuming all of the class action discussion under the conclusion that the district court abused its discretion in certifying a class. The court of appeals, however, expressly ruled that "[i]n addition to the reasons given above ... this class must be decertified because it independently fails the superiority requirement of rule 23(b) (3)." Id. at 746 .

${ }^{31}$ Although the court considered other factors, the maturity of the litigation was 
The court appears to have used the Manual as persuasive authority, ${ }^{52}$ or at least as a type of what Professors Laurens Walker and John Monahan have come to call social authority, which, as noted above, is a shorthand term for empirical propositions that have been tested and accepted as the equivalent of legal rules. ${ }^{53}$ As we will see below, the Castano use of the Manual relies in part on scientifically developed empirical information and in part on the general experience and judgment of the authors of the Manual. ${ }^{54}$

The Castano court ruled, as an independent reason for decertifying the class, that because "the tort is immature, the class complaint must be dismissed." ${ }^{55}$ The court began its Rule 23 superiority requirement analysis by stating that "certification dramatically affects the stakes for defendants. ${ }^{, 56}$ To support that proposition, the court cited the Agent Orange case ${ }^{57}$ and the MCL $3 d^{55}$ Both the Manual and the Bordens and Horowitz study are cited for the proposition that "[a]ggregation of claims also makes it more likely that a defendant will be found liable and results in significantly higher damage awards," a proposition that focuses on one aspect of Bordens's and Horowitz's multifaceted empirical study. ${ }^{59}$ After reviewing some history of Rule

the only factor referred to by the court in its summary of its ruling on superiority. See Castano, 84 F.3d at 740-41 ("[W] hile the tort is immature, the class complaint must be dismissed as class certification cannot be found to be a superior method of adjudication."). In its discussion of superiority, the court also considered whether "individual lawsuits [were] feasible," id., at 748, the "complexity of the choice of law inquiry," id. at 749-50, and the "Seventh Amendment limitations to bifurcation," id. at 751.

${ }^{52}$ See id. at 748-49 (citing the Manual in its discussion of "immature" torts).

${ }^{39}$ See supra note 36 and accompanying text (discussing the idea of equating empirical propositions to legal rules).

${ }^{34}$ See discussion infra at notes 69-75 and accompanying text (commenting on "legislative factfinding"). One commentator remarked that by citing a source cited in the Manuah "the [Castano] court makes one authority appear as two, in the kind of immaculate conception of which law reviews are sometimes guilty." John Burritt McArthur, The Class Action Tool in Oilfield Litigation, 45 U. KAN. L. REv. 113, 201 n.528 (1996).

${ }^{55}$ Castano, 84 F.3d at 740-41.

${ }^{56} \mathrm{Id}$. at 746.

${ }^{37}$ See id. ("Class certification magnifies and strengthens the number of unmeritorious claims." (citing In re "Agent Orange" Prod. Liab. Litig., 818 F.2d 145, 165-66 (2d Cir. 1987))).

${ }^{38}$ See Castano, 84 F.3d at 746.

${ }^{59} I d$. (citing MCL 3D, supra note 24, $\$ 33.26$, at 322 n.1056, and Kenneth S. Bordens \& Irwin A. Horowitz, Mass Tort Civil Litigation: The Impact of Procedural Changes on Jury Decisions, 73 JUDICATURE 22, 22 (1989)). As noted above, the statement in the text of the $M C L 3 d$ is that "[e]mpirical research suggests that decisions to consolidate or bifurcate trials may affect jury decisions about liability and damages." MCL 3D, supra note $24, \S 33.26$, at 322 n.1056. While Bordens and Horowitz found deleterious effects 


\section{3, its Advisory Committee Note, ${ }^{60}$ and Judge Posner's analysis of su- periority in Rhone-Poulenc, ${ }^{61}$ the court concluded its analysis with this quote from the $M C L 3 d$ :}

Fairness may demand that mass torts with few prior verdicts or judgments be litigated first in smaller units-even single-plaintiff, singledefendant trials-until general causation, typical injuries, and levels of damages become established. Thus, "mature" mass torts like asbestos or Dalkon Shield may call for procedures that are not appropriate for incipient mass tort cases, such as those involving injuries arising from new products, chemical substances, or pharmaceuticals.

The MCL $3 d$ cites a law review article by Professor McGovern for that maturity concept, ${ }^{63}$ but the Castano court cited only the Manual. Although the court may have simply been economical in its citations, the exclusive citation appears to attribute more authoritative force to

for defendants, as cited by the court, their findings are not as one-sided as the court's statement indicates. These researchers also found that "the plaintiff with the most severe injuries ... received higher awards in the context of an individual trial [than in an aggregated trial]." Kenneth S. Bordens \& Irwin A. Horowitz, Mass Tort Civil Litigation: The Impact of Procedural Changes on Jury Decisions, 73 JUDICATURE 22, 24 (1989) [hereinafter Bordens \& Horowitz, Mass Tont Civil Litigation]. Given that finding, the Castano court's concern that a defendant could face significantly higher damage awards in the aggregated condition might not be justified. If the percentage of severe cases is high enough, plaintiffs as a whole might recover higher awards through plaintiff-by-plaintiff litigation.

Moreover, in their complete report of the above study, Horowitz and Bordens reported that the presence in a consolidation of a plaintiff with severe injuries made it more likely that the jury would find for the defendants. See Irwin A. Horowitz \& Kenneth S. Bordens, The Effects of Outlier Presence, Plaintiff Population Size, and Aggregation of Plaintiffs on Simulated Civil Jury Decisions, 12 LAW \& HUM. BEHAV. 209, 225 (1988) [hereinafter Horowitz \& Bordens, Outlier Presence] (noting that having a plaintiff with severe injuries in a consolidated action resulted in more verdicts for the defendants, although one would expect it to have the opposite effect). Where the severely injured plaintiff is not included-as in plaintiff-by-plaintiff litigation-the research suggests that it is more likely that a jury would find defendants liable in a given case. See id. ("In some juries the very severity of the outiier's injuries appeared to raise a question of fault, in that doubt may have been cast on whether the company could be so venal as to cause such injuries in pursuit of profit."). In the end, these research findings do not fully support the Castano court's interpretation and reliance on them.

${ }^{60}$ See Castano, 84 F.3d at 746-47 nn.19 \& 23 (citing the Advisory Committee's Note cautioning against certification of a class for mass accidents).

${ }^{61}$ In re Rhone-Poulenc Rorer, Inc., 51 F.3d 1293, 1300 (7th Cir. 1995).

${ }^{62}$ Castano, 84 F.3d at 748-49 (quoting MCL 3D, supra note 24, $\$ 33.26$, at 322).

${ }^{6 s}$ See MCL 3D, supra note 24, $\$ 33.26$, at 322 n.1057 ('Litigation is 'mature' if through previous cases (1) discovery has been completed, (2) a number of verdicts have been received indicating the value of claims, and (3) plaintiffs' contentions have been shown to have merit." (citing Francis E. McGovern, Issues in Civil Procedure: Advancing the Dialogue, A Symposium: Resolving Mature Mass Tont Litigation, 69 B.U. L. REv. 659 (1989))). 
the Manual than I or the editors of the Manual intended or would have expected.

The Castano court appears to have used the $M C L 3 d$ as persuasive authority. As we have seen, the $M C L 3 d$ specifically disclaimed any use as an authority, ${ }^{64}$ and by using the term "may," implicitly disclaimed treatment of maturity as authority. ${ }^{65}$ The court's use raises some unsettling questions addressed below:

- Is the empirical component of the Manual, both in the form of anecdotal accumulations of judicial experiences and of citation to empirical research findings, a type of social authority that should be used to establish the empirical foundation for a rule of law?

- What process should precede a finding of social authority and what standards should be used to evaluate putative social authority?

- How does the addition of a concept like maturity to Rule 23 relate to the rulemaking process established pursuant to the Rules Enabling Act? ? $^{66}$

Ultimately, these questions lead to one final question: Can general and conclusory concepts like maturity be presented in publications like the Manual in a way that lessens the likelihood that they will be converted into legal rules?

\section{A. Legislative Factfinding}

In creating a procedural rule or presumption that only mature mass tort cases are eligible for certification as class actions, the Castano court relied on at least two empirical premises, both addressed in the $M C L 3 d$. The first is that aggregation of claims is harmful to defendants, for which the court cites (and overstates) social science findings summarized in the $M C L 3 d^{67}$ The second premise is that immature mass torts are not appropriate subjects for aggregation. ${ }^{68}$ The latter proposition rests solely on the judgment of the authors of the $M C L$

\footnotetext{
${ }^{64}$ See supra notes $34-35$ and accompanying text (discussing the Manuals disclaimer).

${ }^{65}$ See Castano, 84 F.3d at $748-49$ (citing the MCL $3 d$ 's proposition that "fairness may" demand" that immature torts be litigated in smaller units (emphasis added)).

${ }^{66}$ See 28 U.S.C. $\$ \$ 2071-2077$ (1994).

${ }^{67}$ See Castano, 84 F.3d at 746 (discussing how aggregation significantly raises the stakes for defendants); see also supra note 59 and accompanying text (discussing research findings on the effects of aggregation on plaintiffs and defendants).

${ }^{68}$ See Castano, 84 F.3d at 740-41, 748-49 (declaring that immature mass torts are unsuitable for certification).
} 
$3 d-q u a l i f i e d$ by use of the "may" -and the experiences and law review articles that informed that judgment.

Both of the above propositions fit within the category of legislative facts, that is, facts "which have relevance to legal reasoning and the lawmaking process, whether in the formulation of a legal principle or ruling by a judge or court or in the enactment of a legislative body. ${ }^{.69}$ Adjudicative facts, on the other hand, are "simply the facts of the particular case. ${ }^{70}$ As legislative facts, neither of the above premises are subject to Federal Rule of Evidence 201, which outlines the procedures for taking judicial notice. "No rule deals with judicial notice of 'legislative facts," according to the Advisory Committee." To encourage judges to think about the factual premises underlying an issue in question, the Advisory Committee decided that it would be inappropriate to impose "any limitation in the form of indisputability, any formal requirements of notice other than those already inherent in affording opportunity to hear and be heard and exchanging briefs, and any requirements of formal findings at any level. ${ }^{\$ 2}$ In keeping with that rationale, a court faced with the need to decide a case may take judicial notice of a legislative fact without attending to the formalities of judicial notice and without finding the "fact" to be beyond dispute. $^{73}$

Using the best available empirical information in a fast-changing field such as mass torts carries the risk of prematurely solidifying a procedural rule on the basis of information that has not been tested in either the adversarial or the legislative rulemaking processes. Professor Davis, along with some other commentators, has questioned whether unfettered judicial notice is the most appropriate approach

${ }^{63}$ FED. R. EVD. 201(a) advisory committee's note; see also Kenneth Culp Davis, An Approach to Problems of Evidence in the Administrative Process, 55 HARV. L. REV. 364, 404-07 (1942) (describing the Supreme Court's utilization of legislative facts to inform their legislative judgment on issues relating to law and policy).

${ }^{70}$ FED. R. EVID. 201(a) advisory committee's notes.

71 .

${ }^{72}$ Id. The Committee quotes, with approval, Professor Kenneth Culp Davis's statement: "What the law needs at its growing points is more, not less, judicial thinking about the factual ingredients of problems of what the law ought to be, and the needed facts are seldom 'clearly' indisputable." Id. (citing Kenneth Culp Davis, A System of Judicial Notice Based on Fairness and Convenience, in PERSPECITVES OF LAW 69 (Roscoe Pound et al. eds., 1964)).

${ }^{79}$ Cf. FED. R. EVID. 201(b), which limits judicial notice of an adjudicative fact to "one not subject to reasonable dispute." In addition, an adjudicative fact must be either "generally known" or "capable of accurate and ready determination by resort to sources whose accuracy cannot reasonably be questioned." Id. 
to the finding of legislative facts. ${ }^{74}$ Davis advocates that judges become fully informed about factual premises that support legal rules, while recognizing that a legislative or rulemaking forum may be superior to a judicial forum for finding legislative facts. ${ }^{75}$ In other words, Davis supports using the rulemaking process as the primary vehicle for resolving questions of legislative fact. The implicit criticism of the judicial forum seems to be that any single judge might uncover less than a complete picture of the social science findings or, in the maturity example, the underlying patterns of litigation activity.

In the Castano ruling on maturity, the sources themselves may not be mature. Social science's study of the effects of aggregation remains quite young and active. Whether a single maturation cycle applies to all mass torts has not been determined. ${ }^{76}$ The Castano court relied on a single social science study for its empirical finding on the disadvantages of class actions for defendants. Further studies are in process that may or may not replicate the findings of that single study. ${ }^{7}$

For its conclusion on the maturity factor, the court drew on a

74 See, e.g., KENNETH CULP DAVIS \& RICHARD J. PIERCE, JR., 2 ADMINISTRATIVE LAW TREATISE $\S 10.5$, at $146-47$ ( $3 \mathrm{~d}$ ed. 1994) (explaining that adjudicative facts frequently do not provide an accurate picture of the aggregate of the situation). Commenting on a case involving the question of whether being younger than age 40 was a bona fide occupational qualification for a bus driver, Professors Davis and Pierce conclude that "[t]he legal system is out of gear in committing to a single judge the question whether safety justifies barring those over age 40 from becoming bus drivers. Obviously, the proper governmental mechanism for determining any such question is a rulemaking proceeding." Id. at 149.

${ }^{75}$ See id. (explaining that a rulemaking proceeding is the appropriate mechanism, but that if a court must decide such an issue, scientific studies, analyses, and the positions of relevant administrative agencies should be considered).

${ }^{76}$ To get a sense of the variety of mass torts, see generally Willging et al., Individual Characteristics, supra note 48 (presenting summary information about 50 distinct sets of mass tort cases).

7 See Interview with Irwin Horowitz, Professor, Oregon State University (June 16, 1999). One study appears to have replicated part of the earlier study and, at the same time, to have complicated the issue. See Irwin A. Horowitz \& Kenneth S. Bordens, The Consolidation of Plaintiffs and the Limits of Jurors' Cognitive Proficiencies (1999) (unpublished manuscript, on file with author) (using mock repetitive stress injury ("RSI") trials and finding that the defendant was more likely to be found liable as the number of aggregated plaintiffs increased to a peak of 10 , and that damages increased to a peak of four plaintiffs and were lower per plaintiff when 10 plaintiffs' cases were aggregated). As with the previous study, the benefits and burdens of aggregation seem to be distributed among plaintiffs and defendants. See supra note 59 (explaining that the Castano court's concern that the burden of aggregation is solely on the defendant is unwarranted, and that Horowitz and Bordens have shown that when a severely injured plaintiff is present in a consolidation, a finding for the defendants is more likely). 
manual based primarily on the judgment of its authors. While the text of the Manual was submitted for outside review, ${ }^{78}$ its recommendations had not been subjected to adversarial challenge in the context of specific litigation before Castano. ${ }^{79}$ The district court did not cite the mass tort chapter of the Manual in the main text of its opinion on class certification. ${ }^{80}$ In addition, the Manual is a snapshot of knowledge, fixed in time, about a fast-changing field. Taking judicial notice of recommendations in the Manual risks missing major changes published-or discovered but not published-after 1995.

\section{B. Social Authority Applied}

As we have seen, evidentiary rules regarding judicial notice provide little or no guidance for a judge who conscientiously seeks reliable support in crafting common law rules. ${ }^{81}$ Professors Monahan and Walker offer a model designed to fill that vacuum. ${ }^{82}$ They approach the question of legislative factinding by concentrating on the use of social science findings by courts. Their discussion, however, seems equally applicable to using conclusory statements derived from the Manual.

Monahan and Walker make explicit Davis's implicit criticism of having a single judge determine legislative facts based on a single study, and they propose explicit criteria for evaluating social science. They conclude that " $[c]$ ourts should place confidence in a piece of scientific research to the extent that the research (1) has survived the critical review of the scientific community; (2) has employed valid research methods; (3) is generalizable to the case at issue; and (4) is supported by a body of other research., ${ }^{, 83}$ Monahan and Walker pub-

${ }^{78}$ An earlier version of the mass tort chapter as well as other portions of the Manual were reviewed and discussed at a conference at the University of Pennsylvania Law School on May 13, 1994.

${ }^{79}$ Appellants quoted the Manual in the rebuttal portion of their oral argument in Castano. Record at 64-65, Castano v. American Tobacco Co., 84 F.3d 1069 (5th Cir. 1996) (No. 95-30725). In general, the arguments addressed the subject of maturity only in the sense of whether the claims in the case were novel, which appellants asserted, see id. at 4,7-8,14,21, or traditional fraud claims, as appellees asserted, see id. at 28-29.

${ }^{80}$ See Castano v. American Tobacco Co., 160 F.R.D. 544 (E.D. La. 1995), rev'd, 84 F.3d 734 (5th Cir. 1996).

${ }^{81}$ See supra notes 67-75 and accompanying text (explaining that the evidentiary rules do not deal with legislative facts, and that the judicial system is ill equipped to deal with empirical data relating to issues of policy).

${ }^{82}$ See Monahan \& Walker, supra note 36 , at 495-517.

${ }^{8 s}$ Id. at 499. 
lished the above criteria in 1986, yet their approach is strikingly similar to the standards the Supreme Court developed in 1993 in Daubert v. Merrell Dow Pharmauceuticals, Inc. to govern the admissibility of scientific evidence. ${ }^{84}$ Presumably the threshold for using scientific information to create a rule of law or a presumption would not be lower than the threshold for admitting scientific information into evidence in a single case.

How do the above criteria apply to the social science findings used in the Manual and in the Castano opinion? Innovative and rigorous as it may be, the Bordens and Horowitz study does not satisfy the above criteria. Indeed, it would be unusual for any single study to do so. No doubt the work passed muster in the scientific community; the prestigious and peer-reviewed National Science Foundation funded it ${ }^{85}$ and $a$ peer-reviewed journal published it. ${ }^{86}$ Both the funding and the peerreviewed publication confirm that the authors employed valid research methods.

The Bordens and Horowitz study, however, did not meet Walker and Monahan's third and fourth criteria. It was a single study. ${ }^{87} \mathrm{Al}-$ though it was a seminal article in a new area, it had not been replicated at the time Castano was decided. ${ }^{88}$ Nor, for many reasons, was this single study generalizable to the tobacco litigation or, without further analysis, to any other mass tort litigation. The experimental study dealt with a "prototypical toxic tort case" in which hypothetical plaintiffs had been exposed to a toxic substance by a chemical manufac-

${ }^{84} 509$ U.S. 579,579 (1993). Compare, for example, the Monahan and Walker criteria with the concerns expressed in Daubert about whether a scientific finding has been (1) subjected to peer review and publication, (2) found to be susceptible to testing by scientific methods, (3) found to be reliable, and (4) generally accepted by the relevant scientific community. See id. at 593-95 (setting forth these factors as observations, but not as a conclusive test).

${ }^{85}$ See Bordens \& Horowitz, Mass Tont Civil Litigation, supra note 59, at $24 \mathrm{n} .15$ ("This research ... was supported by a National Science Foundation Grant SES 8609892.").

${ }^{85}$ The study was published in Law and Human Behavior. See id. at 24 n.14 (noting that the work was published in Horowitz \& Bordens, Outlier Presence, supra note 59).

${ }^{87}$ Cf. McArthur, supra note 54, at $201 \mathrm{n} .528$ (criticizing the Castano court's "poor use of social science"). In commenting on the Castano court's use of social science, particularly the Bordens \& Horowitz study, McArthur remarks that "[n]o social scientist, including the authors, would view their study alone as enough support for changing the class-action rule." Id.

${ }_{B s}$ A recent study appears to have replicated parts of the earlier study. See generally Horowitz \& Bordens, supra note 77 (showing that increasing the number of plaintiffs makes it more likely that the defendants will be found liable for increased damages up to a point, and that the burdens of aggregation are not solely on the defendants). 
turer. ${ }^{69}$ Whether lessons from that type of scenario might apply to other products, such as tobacco, and other claims, such as fraud and intentional manipulation of addictive substances, seems questionable. The issues involved in the experimental study differ significantly from the issues raised in tobacco litigation. Those differences need to be analyzed before a court applies findings from a laboratory experiment to real litigation. ${ }^{90}$ Parts III and IV develop a parallel point that is central to this Article: each group of mass tort cases has distinguishing characteristics that argue against applying a single general conceptin this case maturity-across the board.

Use of case management suggestions from the Manual also runs the risk of bypassing the deliberative rulemaking process created by Congress in the Rules Enabling Act. ${ }^{91}$ While Castano was being decided, the Advisory Committee on Civil Rules considered whether a maturity factor should be applied to determine the viability of a putative class action. ${ }^{92}$ A proposed draft published shortly after Castano proposed adding to the terms of the current Rule 23(b)(3)(B) the "maturity of any related litigation involving class members" as another factor for courts to use in determining the superiority of any putative class action, not just a mass torts action. ${ }^{93}$ The Committee received a considerable number of comments from attorneys, bar organizations, and private entities. ${ }^{94}$ Most of the commentators supported adding the maturity factor, but almost half suggested refining or limiting the scope of the proposal. ${ }^{95}$ The proposal was not adopted, but remains

${ }^{89}$ Horowitz \& Bordens, Outlier Presence, supra note 59, at 214; see also McArthur, supra note 54, at $201 \mathrm{n} .528$ ("[T] he case may not even be largely representative of real, tried cases.").

${ }^{90}$ See supra note 48 and accompanying text.

${ }^{91}$ See 28 U.S.C. $\$ \$ 2071-2077$ (1994) (codifying the Rules Enabling Act and describing the rulemaking process).

${ }_{92}$ See 1 RULES COMM. SUPPORT OFFICE, ADMIN. OfFICE OF THE U.S. COURTS, WORKING PAPERS OF THE ADVISORY COMMITIEE ON CTVII RULES ON PROPOSED AMENDMENIS TO CIVIL RULE 23, at 55-56 (1997) (Feb. 1996 Draft) [hereinafter RULE 23 WORKING PAPERS]. The proposed maturity factor is in Rule 23(b) (3) (C).

${ }_{93}$ Id. at 143-44, reprinted in 167 F.R.D. 523, 559 (1996) (August 1996 Draft Published for Public Comment) (underlined terms indicate the proposed changes). The proposal would also renumber Rule 23(b)(3)(B) to become Rule 23(b) (3)(C). See id. at 151 (Committee Note to August 1996 draft) (noting the change in formatting of Rule 23).

${ }^{94}$ See id. at 325-29 (featuring comments from the ABA, Public Citizen Litigation Group, various state bar associations, and others).

${ }_{95}$ See id. (discussing how to limit or to refine maturity by setting forth a more lucid definition, restricting its application to certain kinds of actions, and assuring that maturity considerations will not impede class actions). For example, several attorneys and 
under consideration as of the writing of this Article. If a mass tort committee is appointed, as recommended by the Mass Tort Working Group, ${ }^{96}$ that committee might also consider the proposal.

Using the Manual to reach a result that the Advisory Committee considered but did not adopt bypasses the Rules Enabling Act process that Congress established as the mechanism for altering the Federal Rules of Civil Procedure. As the Supreme Court recently concluded, courts "are bound to follow Rule 23 as we understood it upon its adoption, and ... are not free to alter it except through the process prescribed by Congress in the Rules Enabling Act. ${ }^{.97}$ When the issue being litigated is precisely the same as an amendment being considered by the Advisory Committee, an individual court has no authority to make that change through adjudication. ${ }^{98}$

An argument might be made that the Advisory Committee is only making explicit what is already implicit in Rule 23(b) (3)'s prerequisite that a court find that "a class action is superior to other available methods for the fair and efficient adjudication of the controversy., ${ }^{, 99}$ As I mentioned before, ${ }^{100}$ the superiority requirement invites a court

organizational commentators suggested that the maturity concept be limited to causation questions that are susceptible to scientific proof and not applied to torts involving novel claims of fraud or to securities or antitrust cases. See id. at 325 (Comments of Stuart Savett, Nat'l Ass'n. of Sec. \& Commercial Attorneys) (limiting maturity to claims in which "the element of causation is susceptible to scientific proof"); $i d$. at 328 (testimony of David Weinstein) (noting that maturity could have an adverse effect on antitrust and securities cases). A law professor suggested that the Committee look to the $M C L 3 d$ for a definition of maturity: "[m] aturity is established when prior litigation shows plaintiffs' claims have merit.... [A] number of courts have picked up on that. And I think that derives from Professor McGovern's research and writing back some years ago." 3 RULE 23 WORKING PAPERS, supra note 92, at 162 (Public Hearing, Dallas, Tex., Dec. 16, 1996) (testimony of Prof. Bart McGuire).

${ }_{96}$ See REPORT ON MASS TORT LITIGATION, supra note 48, at 56, reprinted in 187 F.R.D. 293, 319 (" $[\mathrm{T}]$ he Civil Rules Advisory Committee has developed and continues to consider a draft Rule 23 amendment that would emphasize the need to consider maturity as a class-certification factor.").

${ }_{97}$ Ortiz v. Fibreboard Corp., 527 U.S. 815, 119 S. Ct. 2295, 2322 (1999).

${ }^{93}$ See T. Dean Malone, Castano v. American Tobacco Co. and Beyond: The Propriely of Certifying Nationwide Mass-Tort Class Actions Under Federal Rule of Civil Procedure 23 When the Basis of the Suit Is a "Novel" Claim or Injury, 49 BAYLOR L. REv. 817, 837 (1997) (arguing that the maturity concept adds another factor to Rule 23(b) (3)); see also Peter A. Drucker, Class Certification and Mass Torts: Are "Immature" Tort Claims Appropriate for Class Action Treatment?, 29 SETON HAIL L. REV. 213, 216 (1998) (arguing that "Rule 23 should be amended to forbid certification of "immature' tort claims," and citing Eisen v. Carlisle $\mathcal{E}^{2}$ Jacquelin, 417 U.S. 156, 177 (1974) for the proposition that the current Rule 23 bars examination of the merits-and consideration of maturity-before deciding class certification).

${ }_{99}$ FED. R. GT. P. 23(b) (3).

${ }^{100}$ See discussion supra notes 50-51. 
to consider a wide range of case management factors, including maturity. Where better to look than at a manual that is designed to inform case management decisions? The language of Rule 23, however, directs a court to compare alternative approaches. ${ }^{101}$ Establishing a flat rule or even a presumption that immature mass torts may not be certified as class actions exceeds Rule 23's terms. ${ }^{102}$

Upon analysis it appears that empirical statements in the Manual should not-unless updated by expert evidence or, at least, adversarial arguments-be used to support creation of a new rule of law. Absent adversarial presentation, the new rule, whether procedural or substantive, may rest on a faulty or shifting empirical premise. Even after an adversarial development of the legal and empirical questions, when the proposed rule is procedural, summary adoption of Manual recommendations bypasses the rulemaking process. These conclusions suggest that the drafters of the Manual may want to examine alternative ways to address the concept of maturity. We now turn to that discussion.

\section{MATURITY IN MASS TORT LITIGATION}

This Part restates the concept of maturity as used in the mass torts case management literature and tests its universality. It concludes that using maturity to determine whether or not to aggregate sets of mass tort cases is both underinclusive and overinclusive; immature mass torts have sometimes been aggregated successfully, and mature mass torts have not always been aggregated. This Part then summarizes other critiques of applying maturity to mass tort aggregation decisions. This lays the groundwork for the multidimensional approach presented in Part IV.

State-of-the-art mass torts case management can be summarized as follows: "Different judicial strategies should be used at different stages of the life cycle. ${ }^{\text {"103 }}$ Specifically, in the early stages of a given litigation set, judges should employ a traditional approach, which is to "view each case discretely, thus ignoring the effects of cases on one

${ }^{101}$ See FED. R. CrV. P. 23(b) (3) (requiring a finding "that a class action is superior to other available methods for the fair and efficient adjudication of the controversy").

${ }^{102}$ See Malone, supra note 98, at 835 ("Opponents of class certification depart from the predominance and superiority requirements of Rule 23(b)(3) when they argue that the tort must be 'mature' before certification.").

${ }^{103}$ Francis E. McGovern, An Analysis of Mass Torts for Judges, 73 TEx. L. REv. 1821, 1841 (1995) [hereinafter McGovern, Mass Torts for Judges]. 
another." 104 At the later stages, "once the full dimensions of the tort are recognized, a more activist model is appropriate."

To implement the above approach, a judge would "learn all aspects of the litigation and develop a comprehensive management plan to resolve the cases in an orderly manner. ${ }^{\text {106 }}$ This should occur only after the litigation has reached a level of maturity in which "a rough equilibrium of case values ensues as the cases become more routinized and the parties' contentions become more defined." ${ }^{107}$

Professor McGovern has outlined a four-step process for resolving mass torts that have reached maturity. His proposal directly addresses defendants' expressed need for a way to end the litigation and also presents ways of treating future claimants fairly. The steps are: (1) consolidating all cases of a single mature mass tort into one forum; (2) resolving all common issues in that forum; (3) collecting information concerning all injuries; and (4) developing a systematic process for resolving all remaining issues. ${ }^{108}$

To clarify and evaluate the above case management recommendations it may help to divide them into two core propositions: First, that immature mass torts should never be aggregated; second, that mature mass torts should always be aggregated. One might add some qualifiers such as "generally" or "except for pretrial management," but the contrast of examining both an absolute prohibition and an absolute mandate helps focus the debate.

\section{A. Immature Mass Torts}

Positing the first recommendation as a general rule helps illuminate its limits and calls attention to the need for special exceptions and qualifiers. In the end, this exercise leads to the conclusion that decisions about whether and when to aggregate are multifaceted and cannot be determined by maturity alone. In examining maturity, this Part will identify some arguably relevant factors that are shunted aside by giving the maturity factor exclusive or even primary weight.

In fact, immature mass torts have been aggregated. Products li-

\footnotetext{
${ }^{104} I d$. at 1840.

${ }^{105} \mathrm{Id}$. at 1842.

${ }^{106}$ Id. at 1840 .

${ }^{107}$ Id. at 1843.
}

${ }^{103}$ See Francis E. McGovern, Resolving Mature Mass Tort Litigation, 69 B.U. L. REv. $659,690-94$ (1989) (discussing how those steps will reduce transaction costs without sacrificing the individualized treatment and intangible values associated with existing civil procedure). 
ability cases involving Agent Orange, albuterol, and felbatol were aggregated into class actions, leading to settlements before any individual verdicts were on record. ${ }^{109}$ All three sets of cases had been certified as litigation class actions. ${ }^{110}$ Agent Orange cases settled on an optout basis on the eve of trial; ${ }^{\text {II }}$ albuterol settled after forty-two days of trial; ${ }^{112}$ and felbatol settled after a class certification was vacated and remanded by the court of appeals. ${ }^{113}$ For practical purposes, these settlements disposed of the entire litigation. In addition, the first major settlement in the breast implant litigation took place when that litigation was, in the judgment of at least one commentator, relatively immature. ${ }^{114}$

That mass torts have been certified as class actions does not, of course, mean that they should have been certified. These examples only show that the point is debatable and that experience does not direct us toward a general conclusion that class certification is never appropriate for a mass tort. A flat rule or presumption against certifying class actions in immature mass tort litigation would have prevented the aggregation that seemed to make these national settlements possible or, some may argue, necessary.

One could argue, as some have with regard to Agent Orange ${ }^{115}$ and silicone gel breast implants, ${ }^{116}$ that class settlements of immature mass torts are not a good idea, because there is insufficient information upon which to calculate fair settlement values. One should note, however, that these arguments relate to data about the number of claimants, information not directly related to the outcomes of individual trials. As to information about case values, one could counter that experienced lawyers are competent to determine realistic case

${ }^{109}$ See Willging et al., Individual Characteristics, supra note 48, at 5-6, 13-14, 28-30, 7173 (discussing the individual characteristics of each of these mass tort cases).

${ }_{110}$ See id. at 13, 28, 71.

111 See id. at 5, 13-14.

112 See id. at 71 (describing settlement details).

11 See id. at 28 ("After the class certification was vacated and remanded, the parties ... settled more than 200 individual cases.").

114 See JAY TIDMARSH, MASS TORT SETTLEMENT CLASS ACTIONS 11 (Federal Judicial Center 1998) (classifying breast implant cases as "relatively immature").

${ }^{115}$ One participant in the Agent Orange settlement negotiations recalled that, on the eve of settlement, "nobody really knew what the real numbers were." PETER H. SCFUCK, AGENT ORANGE ON TRIAI 162 (1986) (quoting Benton Musslewhite, attorney for plaintiffs in Agent Orange class action).

${ }^{116}$ See TIDMARSH, supra note 114, at 77 ("[T] he settlement had been negotiated in the expectation that only 60,000 claims would be submitted, but approximately 440,000 claims were ultimately filed."). 
values based on cases involving similar injuries. Indeed, lawyers have been able to evaluate liability claims based on prior litigation involving other products. ${ }^{117}$ In this context, a rule or presumption against class action settlements of immature mass tort case congregations would bar outcomes that some litigants and judges have found superior-for whatever reasons-to case-by-case adjudication.

A flat rule or presumption against aggregation or class certification of immature mass torts also sweeps under one rule a vast array of litigation types. For example, the Agent Orange litigation involved an estimated 15,000 claims, while the felbatol litigation involved an estimated 235 claims. ${ }^{118}$ Tobacco litigation, which the Castano court classified as immature, potentially involves $50,000,000$ claims. Whether to aggregate these three differing litigation sets calls for different analyses of manageability. Nevertheless, Castano and the $M C L 3 d$ have been cited in support of denial of class certification in cases involving entirely different sets of injuries and legal theories, primarily claims of fraud, breach of contract, and breach of warranty.

Other differentiating factors may also be brushed aside by a flat rule or presumption. The nature and seriousness of the injuries will affect the feasibility of litigating individual claims. Indirectly, Rule 23(b) (3) calls for an analysis of the seriousness of injuries and the extent of damages. ${ }^{120}$ To say that immature torts dealing with modest-

${ }^{117}$ The Castano court's holding appears to be limited to "novel and wholly untested" theories. Castano v. American Tobacco Co., 84 F.3d 734, 737 (5th Cir. 1996). But the novelty of a claim may be as opaque as its maturity. See Recent Case, Class Actions-Class Certification of Mass Torts-Fifh Circuit Decertifies Nationwide Tobacco ClassCastano v. American Tobacco Co., 84 F.3d 734 (5th Cir. 1996), 110 HARV. L. REv. 977, 980-81 (1997) [hereinafter Recent Case: Castano v. American Tobacco Co.] (positing that a "cause of action may be novel because it is based either on a new theory of liability or on a conventional liability theory applied to a new situation" and concluding that "the Castano claims ... were not immature in either sense of novelty. ...").

${ }^{118}$ See Willging et al., Individual Characteristics, supra note 48, at 3 tbl.1 (providing data regarding 26 personal injury mass tort congregations).

119 See, e.g., Marascalco v. International Computerized Orthokeratology Soc'y, Inc., 181 F.R.D. 331, 339 n.19 (N.D. Miss. 1998) (involving claims for breach of contract, breach of warranty, fraud, and RICO claims by optometrists relating to marketing of corrective vision process, and citing Castano and the $M C L, 3 d$ on the issue of fairness of class certification to the defendant); In re Stucco Litig., 175 F.R.D. 210, 218 (E.D.N.C. 1997) (concerning homeowners seeking class certification for claims alleging fraud, breach of warranty, negligence, and related claims concerning application of a synthetic stucco product to their homes, and citing Castano and the MCL $3 d$ regarding maturity, one of many factors in the court's analysis).

${ }^{120}$ Rule 23(b) (3) provides that one of the factors pertinent to findings of commonality of issues and superiority of administration is "the interest of members of the class in individually controlling the prosecution or defense of separate actions." FED. 
sized claims, such as those relating to polybutylene piping or synthetic stucco in home construction, should not be aggregated may mean that such claims will not be addressed at all because the amount at stake in individual cases may not be enough to support the litigation. Medical monitoring claims generally involve very modest levels of individual damages or costs, yet some argue that monitoring the effects of exposure to a toxic substance-and compensating only those with demonstrable injuries-represents the most rational approach to meeting the tort system's goals of compensation and deterrence. ${ }^{121}$

Another key distinction in mass tort case management relates to whether a group of injuries arose from a single incident as opposed to multiple uses of a single product over time. Single incidents, such as airline crashes and hotel fires, are routinely aggregated and resolved despite the fact that each particular incident could be called an immature mass tort. ${ }^{122}$ The albuterol class was linked by claims arising from the distribution of an allegedly contaminated batch of an allergy drug. Plaintiffs in such cases typically "share the common characteristics of time, place, and cause of injury," and liability "is usually governed by the law of a single forum, although damages might not be." ${ }^{123}$ When deciding about aggregation, maturity seems less relevant than the common features of these cases.

Similarly, factors such as the clarity of the evidence relating to general causation, the ease of identifying the cause of an injury, the dispersal of the cases among various courts, the number of defendants, and the ability of the defendants to pay judgments all seem relevant to decisions about when to aggregate cases. Relying on the

R. CTV. P. 23(b) (3). In 1966, the Advisory Committee recognized that "the amounts at stake for individuals may be so small that separate suits would be impractical." FED. $R$. Crv. P. 23 advisory committee's note. Indeed, the Castano court examined this factor. See Castano, 84 F.3d at 748 ("[T]here is reason to believe that individual suits are feasible.").

${ }^{121}$ For a summary of those arguments, see the discussion in Thomas E. Willging, Mass Torts Problems and Proposals, in REPORT ON MASS TORT LITIGATION, supra note 48 app. $\mathrm{C}$ at 39-42, reprinted in 187 F.R.D. 328, 351-56 [hereinafter Willging, Problems and Proposals]. See generally Elizabeth J. Cabraser \& Fabrice N. Vincent, Class Certification of Medical Monitoring Claims in Mass Tort Product Liability Litigation, in A.L.I.-A.B.A. COURSE OF STUDY MATERIALS: PRODUCTS LIABIITY 1 (July 22-23, 1999) (discussing recent developments in class treatment of medical monitoring claims).

122 See REPORT ON MASS TORT LITIGATION, supra note 48, at 12, 187 F.R.D. at 301 ("Litigation of single-event mass torts has followed traditional methods of aggregation ...."); see also McGovern, Mass Torts for Judges, supra note 103, at 1826 ("The judicial system has handled, without major difficulty, mass torts involving discrete disasters, such as aircraft crashes, building collapses, and train wrecks.").

${ }^{123}$ REPORT ON MASS TORT LITIGATION, supra note 48, at 11-12, 187 F.R.D. at 301. 
single factor of immaturity to rule out class certification or other forms of aggregation elevates the general concept of maturity to a trump card that threatens to obliterate other relevant factors.

\section{B. Mature Mass Torts}

The second proposition-that all mature mass torts should be aggregated as a mechanism for resolving them-also is of doubtful merit when viewed in the context of wildly varying types of mass tort litigation. The pressure to aggregate mature mass torts seems great, but whether or not to succumb to it in a given context continues to be open to debate. ${ }^{124}$ The historical record has not been unequivocal; each closed mass tort seems to have followed a unique path, implying, in the end, that maturity is not the dominant concern.

Three mass torts remain open after reaching maturity: asbestos, silicone gel breast implants, and DES. ${ }^{125}$ Each of the three seems to be following a different path. Asbestos has followed the aggregation model at a national level via a combination of the multidistrict litigation ("MDL") process, numerous bankruptcy proceedings, and efforts at national class action settlements. ${ }^{126}$ Silicone gel has followed what has been called a "devolution" model. ${ }^{127}$ The MDL judge has provided national leadership through pretrial management of discovery, class settlement, and other pretrial actions (including appointment of a national panel of court-appointed experts), while leaving individual case resolution to lawyers and judges in numerous state and federal courts. DES cases have generally not been aggregated (aside from statewide consolidation for pretrial management) and have been resolved over the years in a stream of individual litigation. ${ }^{128}$ A flat rule requiring national aggregation for final resolution would certainly have distorted the path that breast implant and DES litigation has taken. In addition, judges, litigants, and commentators are all painfully aware of the frustrations faced in trying to aggregate and resolve asbestos litiga-

${ }^{124}$ See generally Willging, Problems and Proposals, supra note 121, at 25-31 ("Various commentators express varying opinions on whether and when and for what purposes cases should be aggregated.").

${ }^{125}$ See Willging et al., Individual Characteristics, supra note 48, at 3 tbl.1 (showing the status and maturity of 26 mass torts).

${ }^{126}$ See id. at 14-17 (providing statistics concerning asbestos personal injury claims).

127 See generally Francis E. McGovern, Judicial Centralization and Devolution in Mass Torts, 95 MICH. L. REV. 2077, $2087-88$ (1997) (describing Judge Pointer's decentralized approach to managing the silicone gel breast implant $\mathrm{MDL}$ ).

${ }^{123}$ See Willging et al., Individual Characteristics, supra note 48, at 25-28 (providing statistics on DES-related cancer and reproductive injury claims). 
tion in a single forum.

Looking at mass torts that closed after reaching maturity reveals several more patterns. Dalkon Shield cases, involving a single defendant and its insurer, have been resolved in post-Chapter 11 proceedings largely through the operation of a claimants' trust. ${ }^{129}$ Several other case congregations have been resolved through aggregated proceedings: the Bjork-Shiley heart valve and the HIV blood factors litigations were resolved through opt-out class action settlements; ${ }^{130}$ and TMJ implant and Bendectin cases were each resolved through a mix of individual actions, consolidations, and limited class actions. ${ }^{131}$ On the other hand, cases involving thalidomide, tampons, and MER/29all relatively small case congregations-appear to have been resolved entirely without aggregated proceedings. ${ }^{132}$ Swine flu vaccine cases were consolidated by the MDL panel, but otherwise proceeded individually through administrative and judicial proceedings. ${ }^{133}$

These experiences with mature mass torts suggest that each case congregation has unique characteristics that move it toward a unique resolution. While there are a limited number of models, reliance on a single model flies in the face of experience.

Let us shift ground from the historical examination of mass torts to a more conceptual level. Despite widespread agreement with the general concept of maturity, there are still dissenting views. Elizabeth Cabraser, an experienced plaintiffs' class actions attorney who represented the putative class in Castano, argues that the "immature tort" is

${ }^{129}$ See generally Georgene M. Vairo, Georgine, the Dalkon Shield Claimants Trust, and the Rhetoric of Mass Tort Claims Resolution, 31 LOY. L.A. L. REV. 79, 153-56 (1997) (summarizing data showing that the Dalkon Shield Claimant's Trust approach worked well at resolving claims); Georgene M. Vairo, The Dalkon Shield Claimants Trust: Paradigm Lost (Or Found)?, 61 FORDHAM L. REv. 617 (1992) (discussing the policies and procedures governing the Dalkon Shield Claimant's Trust). A mandatory class action settlement paved the way for consolidation of all claims and funds into a single trust. See In re A.H. Robins Co., 880 F.2d 709, 752 (4th Cir. 1989) (approving both class certification and a settlement order).

${ }^{150}$ See Willging et al., Individual Characteristics, supra note 48, at $32-33$ (Bjork-Shiley heart valve), 34-35 (HIV blood factors). Note that while I classified the heart valve and HIV blood factors litigations as "relatively mature," Professor Tidmarsh judged both to be "relatively immature." TIDMARSH, supra note 114, at 11. These differences may, of course, reflect a half-full/half-empty view of the same phenomenon, but they illustrate the difficulty of making clear and firm judgments about maturity in a given case.

1s! See Willging et al., Individual Characteristics, supra note 48, at 17-19 (Bendectin), 59-61 (TMJ implants).

${ }^{152}$ See id. at 41-42 (MER/29), 57-59 (tampons), 61-63 (thalidomide).

${ }^{23 s}$ See id. at 55-57. 
an "immature concept." In her view, the danger lies in "applying a purportedly rigorous, scientific-sounding concept such as that of 'immature tort" before determining whether there is "evidence that individual litigation and trials of the plaintiffs' claims will actually be cost-effective" for the litigants and the court system. ${ }^{195}$ Cabraser also argues that there is no accepted objective standard as to how many trial outcomes would constitute maturity. ${ }^{136}$ In sum, Cabraser claims that the utility of the "immature tort" concept is "largely unsupported (at least to date) by any widely accepted body of evidence" or by any consensus among lawyers, judges, or scholars. ${ }^{137}$ While Cabraser emphasizes the practical viability of proposed class litigation, her view, like Judge Weinstein's, seems to contemplate judges taking into account the merits of litigation before deciding whether or not to aggregate. $^{138}$ Other commentators advocate explicitly that courts review the merits before ruling on class certification and that the Advisory Committee on Civil Rules adopt an amendment to Federal Rule of Civil Procedure 23 to authorize that practice. ${ }^{139}$

At an even higher level of abstraction, Professor David Shapiro argues for a class action model that views the class as the entity that drives a class action. Under his model, "it makes little sense to defer class certification of what appears to be a mass tort ... until the requisite number of individual actions have been ground through the sys-

${ }^{134}$ Elizabeth J. Cabraser, The Road Not Taken: Thoughts on the Fifth Circuit's Decertification of the Castano Class, in A.L.I.-A.B.A. COURSE OF STUDY MATERIAIS: CTVIL PRACTICE AND LITIGATION TECHNIQUES IN THE FEDERAL COURTS 433, 450 (Aug. 14-16 1996).

${ }^{135} I d$.

${ }^{136}$ See id.; see also David Rosenberg, Of End Games and Openings in Mass Tont Cases: Lessons from a Special Master, 69 B.U.L. REV. 695, 707 (1989) (stating that the "maturity" standard is "too vague to provide courts with useful guidance"); Recent Case: Castano v. American Tobacco Co., supra note 117, at 980 (" $[$ F] or the many cases in which there is some middling number of previous suits, no objective reference exists by which a court can ascertain the number of claims necessary to constitute maturity.").

${ }^{137}$ Cabraser, supra note 134, at 450.

138 See Jack B. Weinstein, Notes for a Discussion of Mass Tort Cases and Class Actions, 63 BROOK L. REV. 581, 590 (1997) (arguing that courts should evaluate the merits "at every phase of a litigation," including the decision whether or not to certify a class); see also infra text accompanying note 145 (documenting, in an empirical study, widespread examination of the merits before deciding class certification).

139 See generally George L. Priest, Procedural Versus Substantive Controls of Mass Tort Class Actions, 26 J. LEGAI STUD. 521 (1997) (arguing that mass torts can only be effectively handled if courts are allowed to substantively review the merits of a claim prior to class certification); Bartlett H. McGuire, The Death Knell for Eisen: Why the Class Action Analysis Should Include an Assessment of the Merits, I68 F.R.D. 366 (1996) (same). 
tem." ${ }^{\text {140 }}$ He poses an alternative that might retain many of the benefits of the maturity theory. Toward that end, Shapiro would certify a class provisionally, conduct discovery and perhaps bellwether trials, and then revisit the certification issue. ${ }^{141}$ Similarly, Professor David Rosenberg would aggregate all potential claimants who have been exposed to a dangerous product or substance and provide medical monitoring for all and compensation to those who develop injuries arising from the exposure. ${ }^{142}$ Rosenberg's approach makes the question of maturity less relevant, if not moot.

Combining the above historical review with the conceptual critiques leads to the conclusion that the core propositions underlying the concept of maturity are, to say the least, not universally applicable. Reviewing experience with mass torts, as well as major proposals to reform case management practices, suggests that a hard-and-fast application of maturity fails to address important components of the complexity of mass tort litigation. Part IV will discuss some of the factors that courts may want to consider when deciding whether or not to aggregate mass tort claims.

\section{BEYOND MATURTTY: A MULTIDIMENSIONAL APPROACH FOR THE MANUAL}

There are any number of approaches that might be used in drafting a new version of the mass tort chapter in the Manual. For example, one could follow a process-oriented approach: guiding judges through the steps that experience shows need to be taken to get a handle on mass tort litigation. These include appointing liaison counsel, setting agendas for Rule 16 conferences, managing discovery processes and dispute resolution, providing for ruling on motions, and selecting cases for trial. This Part discusses a multidimensional

${ }^{140}$ David L. Shapiro, Class Actions: The Class as Party and Client, 73 NOTRE DAME L. REv. 913, 935 (1998). For further discussion of Professor Shapiro's model, see Willging, Problems and Proposals, supra note 121, at 114-15, 123-24.

141 See Shapiro, supra note 140, at 935-36 (noting that "an alternative ... might be to allow provisional certification of a class action when such a tort is brought to the courts").

${ }_{142}$ See generally David Rosenberg, Individual Justice and Collectivizing Risk-Based Claims in Mass-Exposure Cases, 71 N.Y.U. L. REV. 210 (1996) (arguing the benefits of collectivization of claims to be so complete that if individuals were allowed to choose, they would select collectivized adjudication); David Rosenberg, The Causal Connection in Mass Exposure Cases: A "Public Law" Vision of the Tort System, 97 HARV. L. REV. 849 (1984) (proposing a "public law" view that enhances deterrence as well as compensation goals); Willging, Problems and Proposals, supra note 121, at 39-42 (discussing the Rosenberg proposals). 
approach, drawing heavily on work that I undertook for the Mass Tort Working Group. ${ }^{14}$

Two related observations guide the proposition that the Manual examine multiple factors in deciding whether or not to aggregate mass torts. First, factors other than maturity appear to have been important forces in the management of mass tort litigation, suggesting that there has been no single driving force. Second, mass tort case management seems to have evolved into a number of different approaches, each representing a unique response tailored to the different characteristics and contexts of each mass tort case congregation.

Those two historical propositions suggest that a manual cannot provide a simple, heuristic rule-of-thumb that will guide judges in addressing mass torts of varying dimensions. This concluding Part will identify some of the factors that courts might want to review and consider in deciding whether or not to aggregate a group of related cases.

This discussion assumes for the most part that the proposed aggregation satisfies the applicable rules, specifically Rule 23, for class actions, and Rule 42, for consolidations. Case management options are examined within the framework of existing rules.

\section{A. The Merits}

In Eisen v. Carlisle ${ }^{144}$ the Supreme Court generally steered district judges away from examining the merits of class litigation before resolving class certification and notice issues. Empirical research indicates that judges have found ways to avoid the full impact of Eisen, primarily by stretching Rule 23(c)'s "as soon as practicable" timetable for deciding on class certification to allow for prior rulings on motions to dismiss and for summary judgment. ${ }^{145}$ Commentators have suggested a basis for that contemporary practice, namely that a court will want at least to take a glance at the merits of the litigation before de-

${ }^{143}$ See generally Willging et al., Individual Characteristics, supra note 48; Willging, Problems and Proposals, supra note 121.

14417 U.S. 156 (1974).

${ }^{145}$ See Thomas E. Willging, Laural L. Hooper \& Robert J. Niemic, An Empirical Analysis of Rule 23 to Address the Rulemaking Challenges, 71 N.Y.U. L. REv. 74, 104-07 (1996) (documenting in four federal district courts sizeable percentages of rulings on the merits via motions to dismiss and motions for summary judgment before ruling on class certification); see also Bruce I. Bertelsen et al., Notes, The Rule 23(b)(3) Class Action: An Empirical Study, 62 GEO. L.J. 1123, 1144 (1974) (noting that the federal district court for the District of Columbia "showed no reluctance to dismiss or to grant summary judgment" without addressing class action allegations). 
ciding aggregation issues. ${ }^{146}$ This preliminary look would address questions such as: Can one plausibly argue that the product in question had the capacity to cause the type of injuries alleged? Is proffered expert evidence likely to be able to survive a Daubert hearing? In practical terms, is there enough merit in the litigation to warrant the cost and risk of aggregating the claims? ${ }^{147}$

Doubts about the merits may point toward a pilot approach, either through ruling on a summary judgment motion or a motion to dismiss in a prototypical case, or through a trial of one or more bellwether cases. ${ }^{148}$ One recent case has suggested a way of combining a bellwether trial for statistically-selected representative plaintiffs and extrapolation of the results to an aggregate group of claimants. ${ }^{149} \mathrm{Po}-$ tential mass torts that have not matured into viable cases have been rejected when judges conclude that there is no demonstrable capacity of the product in question to cause the type of injuries alleged. Agent Orange, Bendectin, and computer-related repetitive stress injury ("RSI") cases each failed to surmount this basic hurdle.

This approach, of course, is closely related to the concept of maturity, in that the inability of a tort to mature implies a lack of merit. The difference is that delay is not required. A court may find merit or lack of merit in claims without waiting for an indeterminate number of other courts to reach the same conclusion.

${ }^{145}$ See supra notes $138-39$ (citing commentators that suggest judges take into account the merits of litigation before deciding whether or not to aggregate).

${ }^{147}$ Examination of the merits raises some of the same Rules Enabling Act questions that have been addressed above regarding maturity. See supra text accompanying notes 91-98. Inclusion of this factor, however, reflects the reality of contemporary class action practice. See supra note 145 (noting the sizeable percentages of rulings on the merits in district courts).

${ }^{145}$ See Robert T. Krebs, Note, Castano v. American Tobacco Co.: Class Treatment of Mass Torts Is Going Up in Smoke, 24 N. KY. L. REV. 673, 693 (1997) ("Experience is definitely valuable, but there are other alternatives to gaining experience such as the use of mini trials or test cases, rather than dismissing any possibility of aggregate treatment of mass tort claims which lack a trial history.").

${ }^{149}$ See In re Chevron U.S.A., Inc., 109 F.3d 1016, 1019-20 (5th Cir. 1997) (holding "that before a trial court may utilize results from a bellwether trial for a purpose that extends beyond the individual case tried, it must, prior to any extrapolation, find that the cases tried are representative of the larger group of cases or claims from which they are selected"). For an extensive discussion of the Cheoron case by counsel for Chevron, see Richard O. Faulk et al., Building a Better Mousetrap?: A New Approach to Trying Mass Tort Cases, 29 TEx. TECH. L. REv. 779, 805-10 (1998) (discussing the pros and cons of unitary trial formats for resolving mass torts and describing the Cheoron case as an immature tort). 


\section{B. Identifiability of Causative Agent}

Closely related to the merits is the ability to identify the cause of the injuries. Some products leave a mark. Sometimes, the mark is in the form of a signature disease that is exclusively or predominantly caused by exposure to that product, such as mesothelioma with asbestos. $^{150}$ Sometimes, the mark consists of organic evidence of accumulated chemical residues in the body, such as lead in a child's blood. In both of the above examples, tracing the exposure to a particular manufacturer remains necessary, but the identifiability of the cause reinforces the clarity of general causation and increases the number of common features that are evident in the litigation.

Sometimes, the product at issue is uniquely identifiable, such as a medical device that was surgically implanted, or a drug that was prescribed. In such instances, the common features of the litigation would weigh in favor of aggregation, subject to the convergence of other favorable factors.

\section{Number of Potential and Actual Claims}

The number of actual and potential claimants may affect both the decision of whether or not to aggregate a group of cases and the form of any aggregation. A case involving hundreds of potential claims may not need special treatment, whereas a set of cases involving thousands of potential claims calls for a careful balancing of the benefits and dangers of aggregate treatment.

Class action certification under Rule 23(b) (3) requires that notice be sent to all potential members of a class. Notification has the effect of vastly expanding the number of claims by increasing the claims rate, as in the silicone gel breast implant litigation. ${ }^{151}$ The danger of creating a mass litigation seems clear. On the other hand, consolidation under Rule 42 or the MDL procedure does not involve the same risks because the consolidation is limited to claims filed independently. Consolidations may, however, encourage attorneys and potential claimants to come forward with new claims.

150 "Mesothelioma is a type of cancer, once rare, that affects the mesothelial cells that make up the pleural, pericardial, and peritoneal membranes enclosing the lungs, heart, and abdomen, respectively." THOMAS WILLGING, TRENDS IN ASBESTOS LITIGATION 5 n.9 (Federal Judicial Center 1987) (citation omitted).

${ }^{151}$ See TIDMARSH, supra note 114, at 77 (noting that in the initial class action of the silicone gel breast implant litigation the number of claims reached 440,000 when only about 60,000 were originally expected). 
Generally, the number of potential claimants represents the number of purchasers or users (and, perhaps, their immediate family members) that were exposed to the allegedly dangerous product or substance. While most products reach a national audience and generate hundreds of thousands of potential claims, some products, particularly medical devices (such as HIV-contaminated blood factors, heart valves, and pacemaker leads), have a more limited use. ${ }^{152}$ In large national exposure settings, class aggregation before testing the merits of claims may invite a host of claims that are difficult to verify and may turn out to be without merit.

\section{Number of Defendants}

Cases with multiple defendants add complexity to any potential mass tort, especially to decisions about aggregation. Separate liability decisions have to be made in relation to each defendant's product and the circumstances surrounding each plaintiff's exposure to that product. In addition to looking at other factors, courts will need to consider whether the separate features of such cases outweigh the common features. Furthermore, the number of defendants may affect jurisdiction, choice of law issues, comparative negligence, contribution among defendants, and, in the end, the number of substantive legal rules that might apply.

\section{E. Dispersal of Claims}

The number of courts in which claims have been filed may have a marked influence on aggregation decisions. Having all claims bundled in a single court simplifies the choice of applicable law. ${ }^{153}$ If the claims arise under the law of a single state or a limited number of states, the number of common issues will be greater than if the claims are governed by the laws of many states. However, the most troublesome mass tort claims are those that arise from the widespread distribution of an allegedly harmful product. ${ }^{154}$ Even if the claims arise

${ }^{152}$ See Willging et al., Individual Characteristics, supra note 48, at 3-5 (estimating the number of people exposed and the number of claims for a variety of mass tort case congregations).

${ }_{133}$ See Willging, Problems and Proposals, supra note 121, at 96-99 (describing the choice of law problems associated with mass tort litigation).

${ }^{134}$ See generally REPORT ON MASS TORT LITIGATION, supra note 48, at 11-14 ("Dispersed mass torts ... pose problems never anticipated by the present mechanisms for resolving torts."). 
from national distribution of a product, plaintiffs' counsel may propose statewide classes to avoid some of the applicable law and choice of law problems exemplified in the Castano case. ${ }^{155}$ In fact, this is what they did in the tobacco litigation after Castano. ${ }^{156}$

\section{F. Solvency of Defendant(s)}

Insolvency of one or more defendants will have a major impact on decisions about aggregations. In such a case, the choices are generally quite limited: some form of bankruptcy or, possibly, a "limited fund" class action meeting the standards. ${ }^{157}$ In bankruptcy, related cases involving other defendants may be transferred to the jurisdiction in which the bankruptcy was filed. ${ }^{158}$ To a great extent, bankruptcy decisions by the parties are likely to determine the aggregation question.

\section{G. Type of Injury}

Mass tort cases have been composed of several discrete types of injuries: serious bodily injuries, medical monitoring claims relating to exposure to a toxic product, and property damage claims. When combined with the factors identified above, such claims will call for different approaches. Generally, meritorious claims of serious personal injury are supportable on an individual basis, without class action treatment. Perhaps they should be aggregated only as required by the parties to provide a timely resolution of their claims.

Exposure-only, property damage, and fraud cases may need the economies of large-scale litigation to support a fair test of the merits. As indicated above, preliminary testing of the merits-for example, by ruling on a motion to dismiss before deciding on class certification-

135 Castano, 84 F.3d at 749-50 ("The complexity of the choice of law inquiry also makes individual adjudication superior to class treatment.").

${ }^{156}$ See Willging et al., Individual Characteristics, supra note 48, at 63 (noting that "[a]fter the decertification of the Castano class, plaintiffs filed statewide class actions throughout the country").

${ }^{137}$ Ortiz v. Fibreboard, 527 U.S. 815, 119 S. Ct. 2295, 2312 (1999) (holding that having a fund with (1) a definitely ascertained limit, (2) equitable treatment of all claimants who have a common theory of recovery, and (3) exhaustion of the fund to pay claims are the three criteria that are "presumptively necessary" before a limited fund class action may be certified).

${ }^{158}$ See In re Dow Corning Corp., 86 F.3d 482, 495-96 (6th Cir. 1996), cert. denied sub nom. Official Comm. of Tort Claimants v. Dow Corning Corp., 519 U.S. 1071 (1997) (noting that the district court in bankruptcy proceedings has the right to pick the venue for pending claims). 
has become a common case management practice. ${ }^{159}$ Some argue implicitly that such claims should be treated as a class because class certification itself may help to identify whether or not meritorious claims exist. ${ }^{160}$ Without class treatment such claims may never be pursued, perhaps at a social cost of ignoring claims that arose out of a legal wrong affecting large numbers of consumers. Others, of course, point to the costs of class actions themselves and to the barriers and risks associated with determining the merits. ${ }^{161}$ Aspects of those debates are rightfully before Congress and the rules committees.

\section{H. Latent Versus Immediate Effects}

Many mass torts involve exposure to products that do not cause immediate injuries. Their effects may be delayed for years, even decades. For example, injuries from asbestos may remain latent for up to forty years, and DES injuries tend to only appear when the offspring of women exposed to the drug reach adulthood. ${ }^{162}$ Efforts to aggregate mass torts with long latency periods result in the type of "sprawling" class actions that the Supreme Court struck down in Amchem. ${ }^{163}$ In terms of the sprawl factor, cases involving medical devices or other products that have an immediate effect, such as orthopedic bone screws, may be more suitable candidates for aggregated treatment than cases involving products allegedly causing latent injuries.

\section{Maturity}

The concept of maturity brings together a number of factors, including some of those addressed above. Discovery should have been completed, plaintiffs' contentions should be shown to have merit, and an unspecified number of verdicts should have been obtained to es-

159 See supra notes $144-49$ and accompanying text (discussing whether a court should take a preliminary look at the merits of a case).

${ }^{160}$ See Priest, supra note 139, at 564-65 ("There is an important affirmative role for the class action in both the efficiency and corrective justice traditions of tort law."); McGuire, supra note 139, at 37475 (summarizing the benefits of looking at the merits before certifying a class).

${ }^{161}$ See, e.g., Advisory Comm. on Civil Rules, Minutes of Nov. 9-10, 1995, in 1 RULE 23 WORKING PAPERS, supra note 92, at 231, 246 (noting an argument that "with preliminary consideration of the merits, lawyers inevitably will demand an opportunity for discovery ... it will be difficult to limit its scope.").

162 See Willging et al., Individual Characteristics, supra note 48, at 17 (noting that latency periods for asbestos-related conditions range from five to 40 years after exposure); $i d$. at 27 (stating that the latency period for DES is estimated at up to 40 years).

${ }^{163}$ Amchem Prods., Inc. v. Windsor, 521 U.S. 591 (1997). 
tablish the value of cases. ${ }^{164}$ Like the factors discussed above, the maturity framework sets aside the question of whether to aggregate for discovery or other pretrial management.

As with the maturity factor, many of the factors identified above require a consideration of the merits directly and from a number of different angles, such as the clarity of general causation and the identifiability of the causal agent. In the end, the difference between the approach outlined in this Part and the maturity approach boils down to whether or not a number of trial verdicts should be required before a case should be aggregated. That difference, in turn, leads to proposing that judges systematically examine a host of relevant factors that may be elements of maturity. Looking at the number of verdicts and the general merit of the plaintiff's contentions is not enough.

To illustrate the difference between looking at the merits and looking at maturity, imagine a mass tort scenario in which the capacity of a product to cause serious injury is abundantly clear based on replicated epidemiological and toxicological studies. Furthermore, the product's use by plaintiffs is readily identifiable, its marketing and use has been limited, and a single defendant appears to have had prior knowledge of the product's dangers. In that scenario, postponing aggregation until a number of trials have been held may be pointless. The evil associated with premature aggregation is creating a new and expandable mass tort, but in our scenario that is not a concern. The merits of the underlying litigation would serve as the justification of the suit. Aggregation is merely an attempt to control and resolve consistently a large number of similar meritorious cases.

\section{J. Exit Factors}

Aside from aggregation for discovery or other pretrial management, an important test of the practicality of aggregation involves whether it can lead to an outcome that would terminate the litigation without the need for individual jury trials on the merits. Can a trial plan be devised that will address the common issues in a way that contributes meaningfully to the disposition of the case as a whole? This means more than the hope that a trial, once commenced, will yield an aggregated settlement, or that a finding of general causation will assist

${ }^{164}$ See McGovern, supra note 108, at 659 (noting that mature mass torts are "where there has been full and complete discovery, multiple jury verdicts, and a persistent vitality in the plaintiffs' contentions"); see also supra text accompanying notes 103-08 (outlining state-of-the-art mass tort case management). 
later juries in finding specific causation, liability, and damages. Will an approach such as extrapolation of damages from randomly selected representative cases be approved on appeal ${ }^{165}$ Will the parties stipulate to a procedure such as binding arbitration to establish individual damages? Addressing such questions in advance may help avoid piecemeal aggregation that fails to improve on individual trials or small consolidations.

\section{CONCLUSION}

Looking back at the evolution of the Manual for Complex Litigation, it appears that using the concept of maturity as the primary guide to mass tort aggregation decisions (an element of the Manual for which I take responsibility) was out of step with the direction of the Manual. By bundling its component factors into a single concept, maturity became susceptible to the interpretation that it embodies a rule for all cases, not a compendium of specific factors that might guide a judge's thinking about case management options. By unbundling the concept into a number of distinct components, a revised Manual could shift from a rule-based approach toward one in which each judge receives guidance in exercising discretion to devise case-specific management strategies. By identifying and clarifying factors relevant to aggregation decisions, the Manual would serve the purpose of informing judicial case management decisions and guiding the thought processes of judges, without predetermining or dictating the outcome. In this way, the Manual would serve its appropriate role as a source of guidance and stimulation for judges faced with the continuously novel demands of mass tort litigation.

${ }^{165}$ See Willging, Problems and Proposals, supra note 121, at 43-48 (discussing the appellate treatment of statistical sampling of damages cases in class actions). 
